\title{
ЗАОЧНЕ ДОСУДОВЕ РОЗСЛІДУВАННЯ ТА ЗАОЧНИЙ СУДОВИЙ РОЗГЛЯД КРИМІНАЛЬНИХ ПРАВОПОРУШЕНЬ: ТЕОРЕТИЧНИЙ АНАЛІЗ ТА ПРОБЛЕМИ ПРАКТИЧНОГО ЗАСТОСУВАННЯ
}

\author{
Коперсак Д. В., Смоков С. М.
}

у науковій статmі досліджено теоретичні та практичні аспекти заочного розслідування кримінальних правопорушень та заочного судового розгляду кримінальних правопорушень за відсутності підозрюваного чи обвинуваченого, аналізуються норми кримінального процесуального кодексу України, які використовуються під час проведенні спеціального досудового розслідування.

Ключові слова: кримінальне процесуальне право, заочне досудове розслідування, заочний судовий розгляд кримінальних правопорушень, “in absentia”, cneціальне досудове розслідування.

В научной статье исследовано теоретические и практические аспекты заочного расследования уголовных правонарушений и заочного судебного рассмотрения уголовных правонарушений, при отсутствии подозреваемого или обвиняемого, анализируются нормы уголовного процессуального кодекса Украины, которые используются при проведении специального досудебного расследования.

Ключевые слова: уголовное процессуальное право, заочное досудебное расследование, заочное судебное рассмотрение уголовных правонарушений, "in absentia”, специальное досудебное расследование.

Kopersak D. V., Smokov S. M. Pre-trial investigation in absentia and correspondence trial criminal offenses: theoretical analysis, and practical application

The scientific article considers theoretical and practical aspects of in absentia investigation of criminal offenses and absentee trial of criminal offenses, in the absence of a suspect or accused, analyzes the rules of the Criminal Procedure Code of Ukraine, which are used in special pretrial investigation.

The purpose of the scientific article is the article. Comprehensive scientific and practical analysis of the state of special pre-trial (correspondence) investigation of criminal offenses of Ukraine. In improving the legal regulation of the institution of special pre-trial investigation.

The criminal proceedings in the absence of a suspect are called "special pre-trial investigation of criminal offenses", and provides for certain features, and deviations from general rules, and are expressed in the departure of adversarial principles and the direct examination of evidence. In such an investigation of a criminal offense, there is no opportunity to execute a direct delivery of a suspicious message, to question a suspect, to conduct an investigative experiment, to present a person for identification, to receive samples for examination from a suspect, which, in turn, raises problems in practice when conducting a special pre-trial investigation. Also, in conducting a special pre-trial investigation, the suspect, the accused is deprived of the opportunity to challenge the evidence provided, and the lack of the possibility of challenging the evidence provided, in our opinion, is not permissible, as the suspect, the accused has the right to state his interpretation of the event of the offense. Since the criminal process has the task of protecting the person, so that no innocent person was accused or convicted, no person was subjected to unreasonable procedural coercion.

Key words: criminal procedural law, correspondence pre-trial investigation, correspondence trial of criminal offenses, "in absentia", special pre-trial investigation.

Постановка проблеми та її актуальність. Процедура “in absentia” - це спеціальна процедура кримінального провадження (досудового розслідування та судового розгляду) за відсутності обвинуваченого, яка була запроваджена Законом України від 07.10.2014 № 1689-VII «Про внесення змін до Кримінального та Кримінального процесуального кодексів України щодо невідворотності покарання за окремі злочини проти основ національної безпеки, громадської безпеки та корупційні злочини» [11].

Метою статті $€$ дослідити теоретичні та практичні аспекти заочного розслідування кримінальних правопорушень та заочного судового розгляду кримінальних правопорушень за відсутності підозрюваного чи обвинуваченого.

Виклад основного матеріалу. На думку Мазура М., спеціальне досудове розслідування кримінальних правопорушень “in absentia” $\epsilon$ процедурою кримінального провадження досудового розслідування чи судового розгляду, яка здійснюється за відсутності обвинуваченого.

(c) Коперсак Д. В., Смоков С. М., 2020 
Із цим визначенням можливо погодитись, дослідивши правову регламентацію спеціального досудового розслідування “in absentia”.

Розгляд за відсутності обвинуваченого за чинним КПК України передбачено у випадках:

1) видалення обвинуваченого тимчасово або на весь час судового розгляду, відповідно до ч. 1 ст. 330 КПК України (не класична процедура, адже обвинуваченого можливо видалити лише на певний час та він проінформований про розгляд, забезпечено можливість надалі ознайомитись із судовими матеріалами, висловити свої заперечення);

2) спрощений порядок розгляду кримінальних проступків ст. 381, 382 КПК України (провадження без судового розгляду чи без учасників, обвинуваченого, за обов'язковою згодою всіх учасників та обвинуваченого);

3) процедура спеціальне досудове розслідування кримінальних правопорушень і спеціального судового розгляду щодо окремих злочинів, передбачених ст.ст. 2971-2975 323 КПК України [12].

Метою процедури “in absentia” $€$ забезпечення принципу невідворотності покарання у випадках, коли підозрюваний або обвинувачений, знаходячись поза межами України, переховується від органів слідства та суду, ухиляючись від кримінальної відповідальності, та задля підвищення ефективності розслідування окремих злочинів проти основ національної безпеки та громадської безпеки, а також забезпечення конфіскації майна за їх учинення.

Процедура “in absentia” необхідна у ситуаціях, коли в тяжких злочинах $€$ конкретні потерпілі, які домагаються справедливості через притягнення винних до відповідальності. 3 іншого боку, відсутність обвинуваченого під час розслідування та судового розгляду не лише призводить до відсутності реального притягнення до відповідальності, але й несе загрозу порушення прав обвинуваченого, які гарантовані Конституцією України, міжнародними документами. На вагах правопорядку та правосуддя наявні, з одного боку, ефективність провадження, а з іншого - право особи на законне досудове розслідування та справедливий судовий розгляд, де обов'язкове дотримання прав обвинувачення.

Так доцільно розглянути міжнародну практику досудового розслідування та судового розгляду за процедурою “in absentia”. Рішення Великої Палати Європейського суду із прав людини від 01.03.2006 «Сейдович проти Італії», де факти справи полягали в такому: заявнику, якого підоз- рювали у вбивстві, був обраний запобіжний захід у вигляді тримання під вартою, але оскільки його не змогли знайти, то його визнали таким, який переховується від правосуддя, державні органи не змогли вручити йому повідомлення із пропозицією самостійно обрати адвоката, тому заявнику було призначено державного захисника, котрому повідомили про передання справи до суду й дату засідання суду присяжних, адвокат брав участь у судовому розгляді, тоді як заявник був відсутній, та надалі заявника будо визнано винуватим, адвокат не подав апеляційної скарги й вирок набрав законної сили, через два з половиною року заявника заарештували в Німеччині, але німецька влада не погодилась на екстрадицію, оскільки італійське законодавство не гарантувало право на оскарження заявнику такого рішення, прийнятого за процедурою “in absentia”. Уряд не заперечував, що не було жодної офіційної інформації про те, що обвинувачений був повідомлений про дату судового розгляду, Європейський суд зазначив, що необхідно встановити, чи за відсутності отримання офіційного повідомлення заявника можна вважати таким, що знав про притягнення до кримінальної відповідальності і про судовий розгляд настільки добре, щоб мати можливість вирішити питання про відмову від свого права бути присутнім під час судового розгляду або вибрати шлях переховування від правосуддя. Водночас Італія висловила кілька аргументів на користь того, що вона мала право оголосити його в розшук і здійснювати провадження за його відсутності, зокрема за повідомленням очевидців злочину, які вказали, що саме заявник учинив злочин й одразу після цього зник із місця свого проживання. I дійсно, заявник не зміг пояснити й навести жодних конкретних аргументів, чому він так раптово після дати вчинення злочину залишив місце свого проживання, та до того ж під час усього подальшого періоду до затримання його в Німеччині, через два роки, він не вчиняв жодних спроб, щоб дізнатись про здійснення кримінального провадження, оскарження судового рішення. Водночас Європейський суд уважав, що простої констатації того, що особа зникла після вчинення злочину, недостатньо для того, щоб уважати, що така особа достатньо інформована про здійснення кримінального провадження, саме щодо нього, й він міг визначитись, чи брати йому участь у цьому проваджені, чи не брати участі. У зв'язку з цим Європейський суд зазначив, що заявнику не було зроблено жодного повідомлення про притягнення до кримінальної відповідальності, а надалі він не мав ефективних 
засобів для поновлення строку для подання апеляційної скарги або на проведення нового розгляду. Європейський суд визнав порушення статті 6 Конвенції, однак зазначив, що на час розгляду справи в Європейському суді в законодавстві Італії відбулись зміни щодо забезпечення змоги перегляду таких рішень.

Висновок із цієї справи такий: навіть якщо не було переконливих даних про повідомлення особи й це може виглядати як порушення Конвенції, то наявність ефективних механізмів оскарження винесеного рішення за результатами провадження “in absentia” саме собою може вирішити цю проблему. Тобто якщо особа надалі зможе подати апеляційну скаргу на рішення або переглянути його за процедурою нового розгляду, то порушення ст. 6 Конвенції не буде. Право на особисту участь у судовому розгляді прямо не вказано в тексті статті, але на це вказує предмет імітації цієї статті, наприклад «право захищати себе особисто», «допитувати свідків, або вимагати щоб їх допитали», «право на безкоштовну допомогу перекладача, якщо особа не розуміє мову, яку використовують у суді», Європейський суд зазначив, що важко реалізувати вищеназвані права, не бувши присутнім. Тобто право на особисту участь імпліцитно передбачено ст. 6 Конвенції, таке право не $\epsilon$ абсолютним, тому в деяких випадках провадження за відсутності не буде становити порушення ст. 6 Конвенції. Пряма відмова передбачена у процедурі спрощеного провадження (кримінальні проступки), де всі учасники, зокрема обвинувачені, можуть відмовитись від участі в судовому розгляді справи, Європейський суд визначає, що пряма відмова має бути чіткою та за доброю волею, тобто у разі примусу чи під час створення ситуації, коли особа втрачає можливість обирати, така згода про розгляд без участі особи не буде відповідати ст. 6 Конвенції. Непряма відмова виражається в діях обвинуваченого, які свідчать, що він знає про здійснення щодо нього кримінального провадження, але відмовляється від права брати участь у цьому проваджені, прикладом $€$ наявність доказів інформування особи про здійснення щодо неї кримінального провадження. Ст. 6 Конвенції не буде порушена в разі відсутності обвинуваченого, коли держава продемонструвала старанні, але безуспішні спроби вручити повідомлення обвинуваченому. Така ситуація виправдна в особливо резонансних справах (прикладом є вчинені злочини на Донбасі). Наявна певна невизначеність щодо поінформованості особи про проведення кримінального про- вадження щодо неї, що створює потребу в оскаржені й перегляді проваджень щодо таких осіб, як тільки їх буде затримано, та відомо їм про наявність вироку щодо нього [2].

У справі «Санадер проти Хорватії» 12.02.2015, де заявник обвинувачувався у вчиненні тяжких та особливо тяжких військових злочинах, був оголошений у розшук, оскільки перебував на окупованій території непідконтрольній Хорватії, не було доказів про його повідомлення про судовий розгляд, у кримінальному проваджені йому надано було безоплатного захисника. Заявник стверджував про порушення права на оскарження вироку в час, коли він перебував на території Сербїі, поза межею досягнення органів влади Хорватії. Уряд висунув заперечення, що законодавство Хорватії передбачало механізм ініціювання нового процесу розгляду для осіб, які будуть перебувати в зоні досяжності органів влади Хорватії та повідомлять свою адресу на території Хорватії, водночас винесений вирок набирав законної сили, його призупинення належало до дискреційних повноважень суду, ймовірно, визнану винною особу спрямовували для відбуття покарання, де вже потім особа ініціювала перегляд провадження. Тому заявник скаржився, що він був перед вибором - ініціювати провадження щодо перегляду судового рішення й бути позбавленим свободи або переховуватися на свободі від органів влади Хорватії та перегляду судового рішення. Європейський суд зазначив, що неможливість проведення судового розгляду за замовченням може паралізувати ведення кримінального провадження у вигляді зникнення доказів, закінчення строку притягнення до кримінальної відповідальності або явної несправедливості. Таким чином, ураховуючи обставини справи та тяжкість злочинів, хоча й не підпадає під дію строків давності, але $\epsilon$ співмірним із великим суспільним інтересом та інтересом жертв злочинів досягти справедливості. Європейський суд погодився, що проведення слухання за відсутності заявника в цій справі не суперечило само собою ст. 6 Конвенції. Проаналізувавши законодавство Хорватії, Європейський суд дійшов висновку, що право особи на оскарження вироку, винесеного за процедурою “in absentia”, ставиться в непропорційну залежність від того, чи здалась засуджена особа органам влади Хорватії для відбуття покарання. Тому такий процес оскарження вироку Європейський суд визнав як порушення ст. $6 \mathrm{Koн}-$ венції [14].

Резолюція комітету міністрів Ради Європи від 19.01.1973 визначає, що процедура “in absentia” 
не буде порушувати вимог справедливого судового розгляду за таких умов: за своєчасного повідомленні особи про проведення розгляду й надання достатнього часу для підготовки захисту, наявності підтвердження про фактичне отримання такого повідомлення за умови проведення розгляду в загальному порядку, надання права захисту втручатись у цей процес, забезпечення процедури змагальності, надання особі судового рішення, прийнятого внаслідок розгляду, обчислення термінів на оскарження такого рішення, надання особі права на оскарження судового рішення, забезпечення права особи на повторне проведення розгляду в загальному порядку, якщо його відсутність була викликана наявністю поважних причин, про які він не міг повідомити уповноважені органи [7].

Процедура “in absentia” передбачена в Болгарії, Данії, Естонії, Італії, Чехії, Німеччиніа, Швейцарії та деяких інших. У більшості цих країн процедура “in absentia” передбачена щодо нетяжких злочинів (строком до 5 років позбавлення волі або менше). В Болгарії процедура “in absentia” передбачена тільки для тяжких злочинів. У Німеччині діють механізми спонукання особи до явки до суду, це $\epsilon$ тимчасова конфіскація майна, надання гарантії недоторканості для участі у процесі.

Проблемним питанням у КПК України $є$ відсутність чіткої регламентація визначення міжнародного розшуку та міждержавного. Міжнародний розшук уважають таким, який здійснюється за механізмами Інтерполу, а міждержавний - відповідно до угод, двосторонніх чи багатосторонніх, між державами щодо взаємодії в питаннях притягнення осіб до кримінальної відповідальності, наприклад, угоди про правову допомогу у кримінальних справах.

Механізми міждержавного розшуку бувають неефективними, особливо коли розшук стосується осіб, учинені злочини якими стосуються збройних конфліктів на Донбасі, й, вірогідно, місцезнаходження таких осіб - територія Російської Федерації.

Можливість здійснення спеціального досудового розслідування на сьогодні на практиці не реалізується. У зв'язку із проблемою наявності умови про оголошення в міжнародний чи міждержавний розшук, вірогідно, доцільно буде обмежитись положенням оголошення в розшук. Міжнародний розшук оголошується через Інтерпол, який, зі свого боку, відповідно до своїх положень, визначає неможливим оголошення в розшук із політичних мотивів. Провадження, яке підпадає під політичний мотив, визначають посадові особи Інтерполу, що $є$ суб'єктивною категорією та створює можливість визначення Інтерполом кожного заявленого провадження для оголошення особи в міжнародний розшук, як із політичних мотивів. Таке врегулювання створює перепону для початку спеціального досудового розслідування кримінальних правопорушень в Україні та призводить до залежності від рішень Інтерполу.

Інша проблема полягає в забезпеченні механізмів повідомлення про зміст обвинувачення та дату й місце судового розгляду. Чинні механізми не $\epsilon$ досконалими, оскільки передбачено повідомлення за останнім місцем проживання чи перебування, але виникають такі ситуації, коли особи не проживали на території України взагалі чи не проживають на момент розслідування чи розгляду кримінального провадження, а проживають на тимчасово не підконтрольній території, тобто направити повідомлення для таких осіб за останнім відомим місцем проживання фізично $\epsilon$ неможливим через відсутність поштового зв' язку та можливості застосування міжнародно-правової допомоги, оскільки ця територія $\epsilon$ територією, непідконтрольною Україні. Щодо осіб, які проживають на території Російської Федерації, виникає тотожна проблема у зв'язку зі специфічним ставленням влади Російської Федерації до процесу розслідування таких кримінальних проваджень та незацікавленості в належному інформуванні таких осіб про здійснення щодо них кримінального провадження.

$€$ проблема в повідомлені осіб, які підлягають обміну, обмін полоненими, адже таких осіб передають на непідконтрольні території, за їх згодою, та згодою держави, але відсутня практика інформування таких осіб про те, що такий обмін не припиняє кримінальне провадження щодо них. Після здійснення такого обміну виникає проблема - як таких осіб інформувати про дії та рішення у кримінальному провадженні щодо них. Для врегулювання таких правовідносин доцільно було б унести відповідні зміни до законодавства України та запровадити практику, коли під час обміну цю особу інформували про кримінальне провадження щодо неї, сповіщення іiі про публічні місця розміщення публічної інформації щодо її кримінального провадження, комунікативні способи, зазначення iї потенціального актуального місця перебування з можливістю підтримання зв'язку з даною особою, та інші варіанти з метою забезпечення прав даної особи та виконання завдання кримінального провадження. 
Інформування через засоби масової інформації загальнодержавного значення має проблематику у вигляді малої ймовірності ознайомлення з інформацією, розголошеною в таких засобах масової інформації загальнодержавного значення України особами, які не мають відносин із державою Україна. Ефективно у такому разі було створити портал, який би дозволяв ефективно інформувати осіб про здійснення щодо них кримінального провадження та шукати таким особам інформацію щодо себе через процедури персоналізації даних, верифікації особи та подібні ресурси, які доступні в мережі «Інтернет», що можливо надалі використати як доказ поінформованості такої особи про розслідування та розгляд справи.

Також неоднозначні положення чинного КПК України щодо проведення підготовчого засідання. Зокрема, положення про спеціальний судовий розгляд сформульовані так, що це рішення може бути прийнято в підготовчому судовому засіданні, й тоді судовий розгляд відбувається без участі обвинувачуваного. Однак норми, котрі регулюють порядок проведення підготовчого судового засідання, прямо не визначають можливість його проведення без обвинуваченого. Тобто в такій ситуації судді двояко трактують такі норми, адже вважають, по-перше, неможливим проведення підготовчого судового засідання без участі обвинуваченого, тому й неможливо прийняти рішення про здійснення спеціального судового розгляду, по-друге, якщо стороною обвинувачення ставиться питання про здійснення спеціального судового розгляду, то, відповідно, суд може провести таке підготовче судове засідання без участі обвинуваченого. Щоб уникнути такої ситуації, необхідно чітко визначити нормою права такі правовідносин.

В України $\epsilon$ порядок виконання вироків судів іноземних держав, однак порядок виконання заочних рішень суду відсутній.

$\epsilon$ норма про поновлення строку оскарження, апеляційного перегляду справи, однак вона недосконала, розміщена у ст. 305 КПК України, та не враховує особливостей апеляційного розгляду, тобто однозначно сказати, що засуджена особа за процедурою “in absentia” має гарантоване право на перегляд такої справи, неправильно. Право на оскарження для осіб, засуджених за процедурою "in absentia", щодо яких $\epsilon$ однозначно достовірні дані про те, що вони повідомлені про здійснення судового розгляду, винесення вироку, але не з'явились та не брали участі в судовому розгляді особисто чи через свого захисника, створює моти- вацію для зловживання, тому що в таких осіб відсутній стимул для того, щоб своєчасно прийняти участь у кримінальному проваджені, оскільки вони знатимуть, що надалі, якщо їх затримають, у них буде можливість подати апеляційну скаргу, незважаючи на те, що ці особи точно знали про проведення досудового розслідування, судового розгляду, та у процесі таких подій ніщо їм не заважало залучити захисника, прибути особисто, у зв'язку з поважними причинами попросити перенести засідання. Тобто це вольове рішення особи, щодо якої відбувається кримінальне провадження за процедурою “in absentia”, не з'явитись у процесі. Варто переглянути спеціальну процедуру оскарження з урахування такого способу захисту засудженої особи. Така процедура оскарження та перегляду необхідна для осіб, щодо яких відсутні фактичні данні про поінформованість щодо проведення кримінального провадження, процесуальні дії та прийняті рішення, невраховуючи правової презумпції поінформованості (публікація у 3MI). Тоді необхідно передбачити гарантоване право про апеляційне оскарження або новий розглядпротягом певного строку з моменту, коли засуджені особи фактично дізнались про такий вирок. $\epsilon$ недолік апеляційного оскарження в разі, коли суд першої інстанції постановив виправдувальний вирок, а суд апеляційної інстанції постановив обвинувальний вирок, тому якщо буде гарантоване право лише на апеляційне оскарження, засуджена особа буде позбавлена можливості скористатись спеціальною процедурою оскарження, оскільки обвинувальний вирок постановлений самим апеляційним судом, який уповноважений розглядати скарги за спеціальною процедурою. Тому варто запровадити спеціальну процедуру нового розгляду, схожу на процедуру розгляду за нововиявленими або виключними обставинами чи в межах наявних процедур передбачити ініціювання перегляду постановленого вироку за процедурою спеціального розгляду. Така можливість повинна бути надана особам, які були повідомлені належним чином про провадження за процедурою “in absentia”, але з об'єктивних причин не могли бути присутніми (наприклад, перебування під вартою на непідконтрольній території чи були тяжкохворі та не могли прибути, а також інші поважні причини, визначені законом).

Висновки. 3 урахуванням вищезазначеного доцільно:

1) Викласти ч. 2 ст. $297^{1}$ КПК України в такій редакції: “Спеціальне досудове розслідування здійснюється на підставі ухвали слідчого судді 
у кримінальному провадженні щодо злочинів, передбачених статтями 109, 110, 110-2, 111, 112, $113,114,114^{-1}, 115,116,118$, частинами другою-п'ятою статті 191 (у разі зловживання службовою особою своїм службовим становищем), статтями 209, 255-258, 258-1, 258-2 , 258-3, 258-4, $258^{-5}, 348,364,364^{-1}, 365,365^{-2}, 368,368^{-2}, 368^{-}$ ${ }^{3}, 368^{-4}, 369,369^{-2}, 370,379,400,436,436^{-1}, 437$, 438, 439, 440, 441, 442, 443, 444, 446, 447 КК України щодо підозрюваного, крім неповнолітнього, який переховується від органів слідства та суду з метою ухилення від кримінальної відповідальності та оголошений у розшук. Здійснення спеціального досудового розслідування щодо інших злочинів не допускається, крім випадків, коли злочини вчинені особами, які переховуються від органів слідства та суду з метою ухилення від кримінальної відповідальності або оголошені в міждержавний та/або міжнародний розшук, а також вони розслідуються в одному кримінальному провадженні зі злочинами, зазначеними в цій частині, а виділення матеріалів щодо них може негативно вплинути на повноту досудового розслідування та судового розгляду».

2) Викласти ч. 2 ст. 314 КПК України в такій редакції: «Підготовче судове засідання відбувається за участю прокурора, обвинуваченого (або за його відсутності в передбаченому законом разі), захисника, потерпілого, його представника та законного представника, цивільного позивача, його представника та законного представника, цивільного відповідача та його представника, представника юридичної особи, щодо якої здійснюється провадження, згідно із правилами, передбаченими цим Кодексом для судового розгляду. Після виконання вимог, передбачених статтями 342-345 цього Кодексу, головуючий з'ясовує в учасників судового провадження їх думку щодо можливості призначення судового розгляду».

Доцільно внести зміни у ч. 2 ст. 459 КПК України та викласти їі в такій редакції: «Нововиявленими обставинами визнаються:

1) штучне створення або підроблення доказів, неправильність перекладу висновку й пояснень експерта, свідомо неправдиві показання свідка, потерпілого, підозрюваного, обвинуваченого, на яких ґрунтується вирок;

2) перебування під вартою на непідконтрольній території особи, щодо якої проведено спеціальне досудове розслідування, важке захворювання, яке унеможливило прибуття особи, щодо якої проведено спеціальне досудове розслідування;
3) скасування судового рішення, яке стало підставою для ухвалення вироку чи постановлення ухвали, що належить переглянути;

4) інші обставини, які не були відомі суду на час судового розгляду під час ухвалення судового рішення і які самі собою або разом із раніше виявленими обставинами доводять неправильність вироку чи ухвали, що належить переглянути».

\section{Література}

1. Конституція України, Верховна Рада України; Конституція, Закон від 28.06.1996 № 254к/96-ВР. Електронний ресурс. Режим доступу: http: //zakon3. rada.gov.ua/laws/show/254к/96-вр.

2. Конвенція про захист прав людини і основоположних свобод, Рада Європи; Конвенція, Міжнародний документ від 04.11.1950. Електронний ресурс. Режим доступу: http://zakon2.rada.gov.ua/ laws/show/995_004.

3. Кримінальний процесуальний кодекс України, Верховна Рада України; Кодекс України, Закон, Кодекс від 13.04.2012 № 4651-VI. Електронний ресурс. Режим доступу: http://zakon2.rada.gov.ua/ laws/show/4651-17.

4. Про внесення змін до Кримінального та Кримінального процесуального кодексів України щодо невідворотності покарання за окремі злочини проти основ національної безпеки, громадської безпеки та корупційні злочини, Закон України від 07.11.2014 № 1689-VII. Електронний ресурс. Режим доступу: http://zakon0.rada.gov.ua/laws/ show/1689-18.

5. Кримінальний кодекс України, Верховна Рада України; Кодекс України, Закон, Кодекс від 5 квітня 2001 року № 2341-III. Електронний ресурс. Режим доступу: http://zakon5.rada.gov.ua/laws/ show/2341-14/stru/paran3027\#n3027.

6. Про забезпечення прав і свобод громадян та правовий режим на тимчасово окупованій території України. Закон України від 15.04.2014 № 1207-VII. Електронний ресурс. Режим доступу: http: / /zakon5. rada.gov.ua/ laws/show/1207-18/paran2\#n2.

7. Про критерії, які регламентують розгляд, який проводиться за відсутності обвинуваченого. Резолюція № 75(11). Комітет Міністрів Ради Євроnи, 19.01.1973, прийнята на 217 засіданні.

8. Рекомендація № $6 \mathrm{R}(87) 18$ Комітету міністрів Ради Європи державам-членам «Щодо спрощення кримінального правосуддя». Електронний ресурс. Рада Європи, Комітет Міністрів Ради Європи; Рекомендації, Міжнародний документ від 17.09.1987 № 6R(87)18. Режим доступу: http://zakon2.rada.gov.ua/laws/show/994_339. 
9. Постанова ЄСПЛ у справі «Колоцца проти Італії» від 12 лютого 1985 р. Електронний ресурс. Режим доступу: http://www.echr.coe.int/ECHR/EN/ Header/Case-Law/HUDOC/HUDOC + database.

10. Постанова ЄСПЛ по справі «Сейдович проти Італії» від 1 березня 2006 р. [БП], № 56581/00, ECHR 2006-II. Електронний ресурс. Режим доступy: http://www.echr.coe.int/ECHR/EN/Header/CaseLaw/HUDOC/ HUDOC+database.

11. Матеріали вебінару «Кримінальне провадження за процедурою “in absentia” 22.05.2020, за участі судді Верховного Суду Миколи Мазура, Українська Гельсінська спілка із прав людини. Електронний ресурс. Режим доступу: https: / /www.facebook. com/Ugspl/videos/1893510987449520.
12. Постанова ЄСПЛ по справі «Санадер проти Хорватії» від 12 лютого 2015 р., № 66408/12, ECHR 2015-І. Електронний ресурс. Режим доступу: http: / / base.garant.ru/71198808/.

Коперсак Д. В., ад'юнт кафедри кримінального процесу Одеського державного університету внутрішніх справ

Смоков С. М., кандидат юридичних наук, професор, професор кафедри кримінального процесу Одеського державного університету внутрішніх справ 